This item was submitted to Loughborough's Research Repository by the author.

Items in Figshare are protected by copyright, with all rights reserved, unless otherwise indicated.

\title{
Loan guarantee schemes for SMEs - the experience in Malaysia
}

PLEASE CITE THE PUBLISHED VERSION

http://dx.doi.org/10.3362/0957-1329.1996.013

PUBLISHER

(C) Practical Action Publishing

VERSION

AM (Accepted Manuscript)

LICENCE

CC BY-NC-ND 4.0

REPOSITORY RECORD

Boocock, Grahame, and Mohd Noor Mohd Shariff. 2019. "Loan Guarantee Schemes for Smes - the Experience in Malaysia". figshare. https://hdl.handle.net/2134/8191. 
This item was submitted to Loughborough's Institutional Repository (https://dspace.lboro.ac.uk/) by the author and is made available under the following Creative Commons Licence conditions.

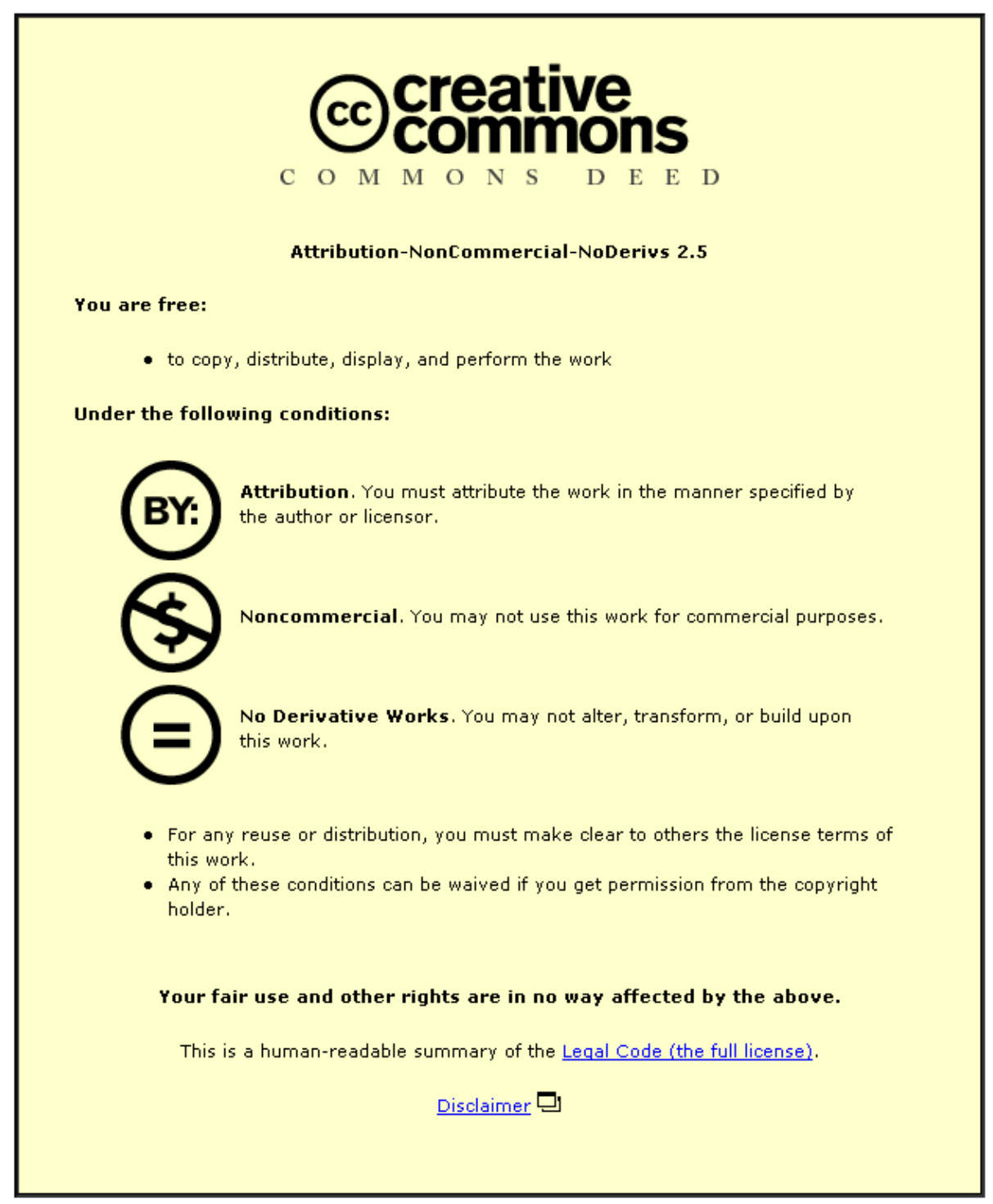

For the full text of this licence, please go to: http://creativecommons.org/licenses/by-nc-nd/2.5/ 


\title{
Loan guarantee schemes for SMEs - the experience in Malaysia
}

\author{
GRAHAME BOOCOCK AND MOHAMMED NOOR MOHAMMED SHARIFF
}

Government-backed loan schemes have been introduced in many countries to enable small and medium-sized enterprises (SMEs) to have access to funding at a reasonable cost. This paper evaluates the schemes offered in Malaysia by the Credit Guarantee Corporation (CGC). The introduction emphasises the importance placed on the SME sector in achieving fully-industrialised status for Malaysia, and highlights the fact that the CGC has been charged with a critical role in assisting SMEs. The paper then describes the operation of the CGC and its place within the spectrum of finance aimed at SMEs, before presenting the findings of an empirical review. Three key areas are explored: the relationship between small firms, banks and the CGC; the level of finance additionality in evidence; and the level of economic additionality generated. In each of these areas, the CGC's effectiveness in meeting the needs of SMEs, banks and the wider economy appears to have been limited. The paper then describes a radical new Scheme introduced by the CGC and assesses whether this Scheme will enable the CGC to achieve its objectives, notably a greater degree of finance and economic additionality. Finally, the implications of the CGC's experience for other developing countries are summarised. 
Small and Medium-sized enterprises (SMEs) in both developed and developing countries are perceived to play a crucial role in the economy. However, businesses may never fulfil their potential if apparently viable SMEs face difficulties in obtaining external funding from private sector financial institutions, notably commercial banks. As a consequence, government-backed loan schemes have been introduced in many countries, enabling smaller enterprises lacking security to obtain bank funding at a reasonable cost. This article concentrates on the facilities offered in Malaysia by the Credit Guarantee Corporation (CGC).

The economic strength of Malaysia was based historically on commodities such as rubber and palm oil. Over recent years, industrialization has accelerated: the government is committed to a strategy of growth led by the private sector, an extensive privatization programme is in place, inward foreign investment is being attracted, and capital- and technology-intensive industries are encouraged. The experience of newly industrialized countries in Asia, and of Japan, suggests that SMEs can play a crucial role in supporting balanced growth across a modern economy. In Malaysia, official support for SMEs has been progressively increased, although the sector remains "very fragmented and characterized by a lack of product differentiation and appropriate technology" (Bank Negara, 1992).

When the CGC was established in 1972, many small firms had to resort to noninstitutional sources of finance charging exorbitant rates of interest. This situation still prevailed in the 1980s, despite the efforts of the CGC and other government bodies (Fong, 1990). There is still a perception in official quarters that SMEs lack appropriate financial support, hence the CGC has recently been restructured and strengthened.

Previous attempts to measure the effectiveness of the CGC - as part of a major World Bank study (Levitsky and Prasad, 1987) and by Malaysian academics, for example Chee (1986, p.100-107) and Phang Hooi Eng (1992, p.128-34) - have used secondary data to describe its schemes in fairly general terms or to concentrate on one aspect of its operations, notably the default rate of guaranteed firms. In other countries, reports on comparable schemes, for example, the United Kingdom's Loan Guarantee Scheme (Robson Rhodes, 1984; NERA, 1990; and, Pieda, 1992) and Small Business 
Administration Loans in the United States (Rhyne, 1988; and, Pletcher and Tootelion, 1989) have addressed more important issues, such as whether the respective schemes add to, or simply replace, existing sources of funding.

The pilot study, on which this article is based, adapts the methodology used in the UK studies for the Malaysian context. For the first time, empirical analysis is presented on critical issues affecting the CGC's performance.

The structure of this paper is as follows:

- the operation of the CGC is described, together with a brief assessment of its role within the financial spectrum

- $\quad$ the survey methodology is outlined

- $\quad$ the findings of the survey are presented, focusing on the relationship between borrowers, banks and the CGC; and, finance and economic additionality

- $\quad$ a radical new scheme introduced by the CGC is described; the likelihood of this Scheme enabling the CGC to achieve its objectives is explored, and the lessons of the CGC's experience for other developing countries are briefly summarised.

\section{The Operation of the Credit Guarantee Corporation}

The CGC provides guarantee cover for credit facilities extended to SMEs in three broad sectors: general business, agriculture and manufacturing. The general business sector is dominant, typically wholesale and retail outlets, small-scale construction firms and hawkers and petty traders.

Bank Negara, the Central Bank, issues guidelines (effectively quotas) covering the amount of CGC-linked lending to be undertaken. This policy has a pervasive influence on the utilization of the schemes. (Malaysia is believed to be unique in operating a 
formal quota system, although various methods are employed elsewhere to encourage participation. In Korea, for example, banks contribute annually to a fund from which loans are granted.) Penalties are levied on individual banks for non-compliance with targets, which happens frequently. Around half of the banks failed to comply with their individual targets over the two-year period until March 1993.

The guidelines also incorporate an obligation to assist the indigenous Malay community (Bumiputeras). Over the CGC's life-time, such firms have accounted for 55 percent of the number and approximately 30 percent of the value of loans.

Since 1972, four main facilities have been offered by the CGC:

- $\quad$ The General Guarantee Scheme (GGS), operating during 1972-81;

- $\quad$ The Special Loan Scheme (SLS), during 1981-8;

- $\quad$ The Principal Guarantee Scheme (PGS), during 1989-94;

- $\quad$ The New Principal Guarantee Scheme, from 1994 to the time of writing.

The introduction of each new scheme has resulted in an increase in the number and value of loans granted, but momentum has not been sustained (refer to Table 1 overleaf). In 1989, the CGC decided to phase out the semi-dormant General Guarantee Scheme and the declining Special Loan Scheme and replace them with the Principal Guarantee Scheme (PGS).

Compared to the previous schemes, the PGS offered: support to larger firms, businesses with net assets or shareholders' funds of up to RM500,000 (RM: Malaysian Ringgit; approximately RM4 = £1); a higher limit on credit facilities of RM500,000; and an increased guarantee, typically 70 percent of the value of the loan (raised from 60 percent in prior schemes). The interest rate was initially fixed at 1.5 percent above Base Lending Rate (BLR); whereas until 1987 the rates of interest charged on CGC loans were very low, and fixed. The revised margin more accurately reflected the risks inherent in lending to SMEs, and allowed the banks to earn a reasonable return in meeting the quotas. It is significant that the supply of PGS loans slowed down sharply 
when an interest rate cap of 9 percent was enforced by Bank Negara over most of 1991 and the first part of 1992. The guarantee premium was set at 0.5 percent of the guaranteed portion of the facility, compared to 0.5 percent of loan value under the SLS.

Table 1. The CGC: number and value (in RM millions) of approved loans, 1980-94

\begin{tabular}{|c|c|c|c|c|c|c|c|c|}
\hline \multirow[t]{3}{*}{ Year } & \multicolumn{8}{|c|}{ Types of Loan } \\
\hline & GCS & GCS & $S L S$ & $S L S$ & PGS & PGS & New PGS & NPGS \\
\hline & No. & Value & No. & Value & No. & Value & No. & Value \\
\hline 1980 & 6,103 & 124.3 & & & & & & \\
\hline 1981 & 1,148 & 25.8 & 17,161 & 498.2 & & & & \\
\hline 1982 & 294 & 9.7 & 16,664 & 519.3 & & & & \\
\hline 1983 & 236 & 7.2 & 10,327 & 298.3 & & & & \\
\hline 1984 & 150 & 4.0 & 7,841 & 208.2 & & & & \\
\hline 1985 & 77 & 2.7 & 5,295 & 140.0 & & & & \\
\hline 1986 & 40 & 1.8 & 4,560 & 122.5 & & & & \\
\hline 1987 & 33 & 1.3 & 3,346 & 75.2 & & & & \\
\hline 1988 & 20 & 0.7 & 2,450 & 49.8 & & & & \\
\hline 1089 & 5 & 0.3 & 1,032 & 21.4 & 1,638 & 78.5 & & \\
\hline 1990 & & & & & 5,641 & $\mathrm{n} / \mathrm{a}$ & & \\
\hline 1991 & & & & & 3,349 & 206.3 & & \\
\hline 1992 & & & & & 2,180 & 174.7 & & \\
\hline 1993 & & & & & 2,302 & 205.8 & & \\
\hline 1994 & (2 months) & & & & 352 & 32.0 & & \\
\hline 1994 & (10 months) & & & & & & 3,146 & 530.1 \\
\hline
\end{tabular}

Notes: GGS: General Guarantee Scheme; SLS: Special Loan Scheme; PGS: Principal Guarantee Scheme (withdrawn 28 February 1994); New PGS: New Principal Guarantee Scheme (from 1 March 1994)

Source: CGC

Other schemes operated by the CGC since 1986 include those aimed at hawkers and petty traders and their trade associations. Since 1986 , over 23,000 guarantees to this group have been approved, involving loans with an average value of only RM2,600, and amounting to RM59.7m. While these schemes have been modest in value terms, they appear to have played a key role in shaping bankers' perceptions of the CGC - a point taken up in the survey findings.

The importance of CGC loans (and conventional bank finance) for SMEs in Malaysia has declined over recent years. While the value of credit facilities extended by the core banking system (commercial banks and finance companies) to smaller enterprises had 
nearly doubled over the five years to 1993, to approximately RM10bn (Bank Negara, 1993), most of the increase stemmed from lending by finance companies. The value of outstanding CGC loans, RM599m, represented only 6 percent of the core banking system's lending to small firms in 1993. SMEs also have access to funding from other sources, including publicly backed development finance institutions (DFIs) and private leasing and factoring companies. Outstanding credit facilities to small firms from outside the core banking system were thought to be around RM9-10bn in 1993 (Lin, 1994).

To counter the drift away from bank financing, the CGC launched the New Principal Guarantee Scheme (New PGS) in early 1994. The New PGS is discussed in more depth after an empirical analysis of the "old" PGS.

\section{The Survey}

Our objective was to conduct a pilot study of firms which had utilized the Principal Guarantee Scheme, adapting the research methodology used by NERA (1990) and Pieda (1992) in evaluating the Loan Guarantee Scheme in the United Kingdom. Using a semi-structured check list of questions, separate interviews were conducted with borrowers and their bankers over the summer of 1994. A number of questions centred on the way in which businesses were funded, clearly a sensitive topic for entrepreneurs. Reliance on postal questionnaires would have yielded a disappointing response. The bank representatives were generally experienced lenders used to dealing with the CGC.

Lists of guarantee recipients in two states within travelling distance of University Utara Malaysia, Kedah and Penang, were obtained from the CGC. Although the population of CGC-backed firms reflects the fact that Kedah is oriented towards agriculture and general business, whereas Penang is a major centre of manufacturing, the majority of firms in both states is engaged in "general business". From a selected sample of 25 firms in each State, the final sample was 32 firms. These were mainly retail or wholesale businesses, or firms engaged in construction or computer-related activities. 
The sample contains only three manufacturing firms, reflecting the small number of manufacturers in the underlying population.

The reasons for non-participation by selected firms illustrate the problems of conducting research in a mixed-race, multi-lingual, developing country; for example: it was not possible to locate a number of firms, as maps of rural Malaysia are notoriously inaccurate; two borrowers had ceased to trade and were in default; and, others (mostly Chinese) were not willing to disclose any information. Non-participants were not replaced, mainly because of constraints on time and resources, and it was judged to have been impossible to include defaulting firms in the sample.

\section{An Evaluation of the Effectiveness of the PGS}

The survey responses, presented in aggregate to preserve confidentiality, are grouped around three key areas:

- the existing (and future) relationship between borrowers, banks and the CGC;

- finance additionality: whether the CGC loans provide additional or replacement finance;

- economic additionality: how much additional economic activity (increased sales, profits or employment) stems from the activities of companies which receive CGC loans?

\section{Relationship: SMEs, Banks and the CGC}

The CGC is approached only after a request for conventional bank funding has been refused; the bank has to confirm that finance would have been offered if collateral were available. A useful starting point was to establish an accurate picture of how this system operates in practice.

Only a small minority of borrowers (3 out of 32) knew of the CGC's existence before the guarantee was issued. The majority (25) learned of the CGC from their bankers, and the remainder (4) became aware of it through friends or the press. Most borrowers (26 
out of 32) had obtained the CGC funding through their usual bank, and they had relied on that bank to apply for the guarantee on their behalf. It was evident that the CGC has preserved a very low public profile, operating at arm's length from its ultimate clients, the SMEs, a situation which does not prevail in other countries (Levitsky, 1993, p.6). In such circumstances, the CGC cannot hope to influence the attitude or ability of the debtor to repay the loan. In the absence of a relationship between the CGC and its SMEs, it is vital to engender a spirit of partnership between the lenders and the guarantee provider (Levitsky and Prasad, 1987). This would involve sharing the risks and rewards of the CGC loans in an equitable manner.

The interest rates on CGC loans were, as stated above, set at artificially low levels by the authorities in the 1980s. This policy distorted allocative efficiency. The banks' natural reaction was to ration credit, as the returns did not reflect the risks involved (Greenwald, Weiss and Stiglitz, 1984). Bank Negara had to set guidelines to force the commercial banks to lend. The imposition of financial penalties for non-compliance was hardly conducive to building a strong partnership. Furthermore, there was no evidence in our study that raising the interest margin (to 1.5 percent above BLR) had resulted in the active promotion of CGC loans by the banks, a point taken up later. .

Another important factor in creating a partnership is the proportion of the loan that is guaranteed. In the case of the PGS, the standard level of cover was raised to 70 percent; the bankers were generally satisfied with the 30 percent level of residual risk, although this remained high by international standards. Whatever the chosen level of cover, however, confidence will be shaken if disputes arise over claims for repayment.

This aspect of the CGC's operations received scathing criticism by Levitsky and Prasad (1987, p.56), who described the CGC as a passive institution which kept its liabilities to a minimum by rejecting claims on the grounds of technicalities. The CGC publishes figures for loans classified as non-performing (NPLs), on which, in official loan schemes operating elsewhere, the payment of claims would be almost automatic. In Malaysia, the situation is very different (see Table 2 overleaf). 
Table 2. Credit Guarantee Corporation Liabilities

\begin{tabular}{|c|c|c|c|c|c|c|}
\hline \multirow[b]{2}{*}{ Year } & \multicolumn{3}{|c|}{ Non Performing Loans ${ }^{1}$} & \multicolumn{2}{|c|}{ Claims Processed } & \multirow{2}{*}{$\begin{array}{l}\text { Claims Paid } \\
\text { Value }(R M m)\end{array}$} \\
\hline & Number & $\begin{array}{l}\text { Value } \\
\text { (RMm) }\end{array}$ & $\%^{2}$ & Number & Value $(R M m)$ & \\
\hline 1984 & $\mathrm{n} / \mathrm{a}$ & 114.8 & 12.3 & 232 & 1.32 & 0.13 \\
\hline 1985 & $\mathrm{n} / \mathrm{a}$ & 151.4 & 17.8 & 202 & 1.87 & 0.10 \\
\hline 1986 & 12,208 & 201.2 & 26.8 & 210 & 1.99 & 0.25 \\
\hline 1987 & 13,902 & 229.3 & 34.2 & 221 & 2.02 & 0.54 \\
\hline 1988 & 12,709 & 239.5 & 40.7 & 228 & 2.74 & 0.65 \\
\hline 1989 & 11,589 & 236.3 & 49.2 & 604 & 2.92 & 1.04 \\
\hline 1990 & 10,515 & 223.2 & 38.9 & 909 & 9.10 & 1.19 \\
\hline 1991 & 9,588 & 215.0 & 35.7 & 641 & 8.40 & 2.02 \\
\hline 1992 & 8,467 & 209.0 & 36.0 & 301 & 3.90 & 1.30 \\
\hline 1993 & 7,787 & 184.8 & 34.0 & 449 & 5.30 & 2.40 \\
\hline
\end{tabular}

Notes:

1. Banks' estimate of potential bad debts

2. Non-performing loans as a percentage of outstanding CGC loans

Source: Kanbur, Boocock and Hwa (forthcoming)

Over the period 1986-93, the CGC processed 3,563 claims, totalling RM36.4m; only 1,505, totalling RM9.3m, were settled. The remaining 2,058 claims, totalling RM27.1m, were either rejected by the CGC or withdrawn by the banks. The CGC's justification for rejecting claims on a retrospective basis relied on judging the quality of the initial appraisal, or the subsequent monitoring, of a loan to be poor. On the basis of the figures in Table 2, one would expect that problems experienced in claiming under the guarantee would be a frequent source of complaint. In fact, the bankers in the pilot study put forward a range of views on this topic. It was generally acknowledged that much of the blame for non-recoverable loans lay at the banks' doors; nonetheless, there were requests for the publication of data on defaulters, to identify whether certain types of borrowers were prone to failure. On similar lines, it was generally accepted that the claims procedure had improved, but some participants (7/32) specifically requested that the CGC should speed up, and simplify, the processing of claims.

At present, it would appear that the banks, rather than public funds, have to bear the bulk of the losses stemming from bad debts. However, the cost of operating the CGC is not publicly available, and the gap between the CGC's income and expenditure is difficult to calculate. The CGC derives its income from a number of sources (including 
the premium charged for the issue of guarantees and interest arbitrage on inexpensive funds received from Bank Negara, and Table 2 did not demonstrate a consistent relationship between non-performing loans and subsequent payments to banks.

Finally, even though our survey dealt with loans granted under the PGS, there were numerous complaints from bankers about heavy losses suffered with the hawkers and traders loans. The high level of bad debts sustained on these small loans, allied to an inability to receive payment under the associated guarantees, has made some bankers reluctant to direct any borrowers to the CGC.

\section{Finance Additionality}

In the United Kingdom, the level of finance additionality generated by the Loan Guarantee Scheme has been subject to close scrutiny. Initially, Robson Rhodes (1984) suggested that less than one-half of the loans were genuinely additional, a pattern which was confirmed by NERA (1990). The latest survey (Pieda, 1992) indicated that 68 percent of the scheme's lending was additional, a remarkable improvement. However, Pieda did point out that a high default rate was associated with cases of high finance additionality, typically lending to entrepreneurs with no record of achievement, or to businesses with little prospect of generating high returns.

The situation in Malaysia is complicated by the Bank Negara quotas. Under pressure to meet targets, bankers may have utilized CGC loans to support inappropriate, high-risk lending, thus contributing to the high level of non-performing loans. Alternatively, the requirement to fulfil quotas may have tempted lenders to substitute CGC loans for conventional borrowing (Chee, 1986b, p.75).

In framing the rules for the PGS, a prime objective was to increase finance additionality. As a consequence, the guarantee issued under the PGS covered only that portion of the total bank package exceeding the amount considered to be adequately backed by collateral. The secured element of the bank finance did not require a guarantee hence 
the risk inherent in CGC loans was significantly increased. The influence of these changes was explored in our study.

Borrowers were asked: "If your application for a CGC loan had not been approved, or if the CGC has not existed, would you have been able to raise the funds in some other way?" The responses are summarised in Table 3.

Table 3. Would you have been able to raise the funds elsewhere?

\begin{tabular}{lcl}
\hline Response & $\begin{array}{c}\text { Number of } \\
\text { responses }\end{array}$ & Explanation given \\
\hline Yes & 10 & $\begin{array}{l}\text { Conventional bank funding could have been accessed; but the CGC } \\
\text { was preferred because the loan was cheaper }\end{array}$ \\
Yes & 4 & Another government-backed agency would have been approached \\
Yes & 5 & Friends, relatives or illegal sources would have been approached \\
N/A & 4 & $\begin{array}{l}\text { Funds were not really required at all } \\
\text { Funds were not available elsewhere - these were cases of genuine } \\
\text { No }\end{array}$ \\
& 9 & Additionality
\end{tabular}

The next step was to ask the bankers to estimate the amount that they would have been able to lend if CGC support had not been available. Table 4 (overleaf) reveals that the 32 firms received bank funding totalling RM2.28m; CGC loans accounted for RM1.11m, and RM1.17m was advanced through conventional bank lines. The PGS aims to provide "top-up" funds hence the CGC loans should have represented 100 percent finance additionality. However, the bankers conceded that they could have granted facilities totalling RM1.58m, reducing the additionality of the CGC loans from RM1.11m to RM697,000 (63 percent of their value).

There were 13 out of 32 cases where discrepancies arose between reported and estimated additionality, and 10 of these could be classed as zero additionality; for example, firms $A$ and $C$ in Table 4 could have obtained the required funding under normal bank lines. In most cases, the bankers would have been prepared to grant the facility unsecured, based on the borrower's sound track record, or they would have given a higher than normal value to the offered security. Alternatively, there were assets in the background which could have been used to secure the borrowing. 
Table 4. The CGC: Finance Additionality (all figures: RM thousands)

\begin{tabular}{|c|c|c|c|c|c|}
\hline \multirow[t]{2}{*}{ Firm $^{1}$} & \multicolumn{3}{|c|}{ Funding package from bank } & \multirow{2}{*}{$\begin{array}{l}\text { Bankmax } 2 \\
\text { amount \% }\end{array}$} & \multirow[t]{2}{*}{ Est. Add. ${ }^{3}$} \\
\hline & Bank & CGC loan & Total & & \\
\hline$A$ & 0 & 5 & 5 & 5 & $0(0)$ \\
\hline B & 30 & 15 & 45 & 30 & $15(100)$ \\
\hline C & 103 & 17 & 120 & 120 & $0(0)$ \\
\hline
\end{tabular}

Aggregate Figures: Total Sample

\begin{tabular}{llllll}
32 & 1,166 & 1,110 & 2,276 & 1,579 & $697(63)$ \\
\hline
\end{tabular}

Notes:

1. The top three rows show the calculations for 3 companies selected at random.

2. Bankmax = an estimate of the maximum available level of bank credit, if the CGC had not existed.

3. Est. Add = the estimated level of finance additionality, after taking into account what the bank could have advanced.

Despite the comments above, the results for the PGS appear impressive, with 63 percent of the value of CGC loans classed as additional finance. This compares favourably with the UK Loan Guarantee Scheme, where the NERA (1990) and Pieda (1992) studies showed additionality of 48 and 68 percent respectively. The statistics, however, are not comparable: Tables 3 and 4 incorporate information relating to bank finance only, whereas the UK studies included data on non-bank funding.

Table 3 revealed (Rows $2 \& 3$ ) that nine borrowers could have obtained non-bank finance. These claims seem plausible, as SMEs have increasingly sought funding from other financial institutions or government agencies. However, the borrowers were generally unwilling to give precise information on alternative sources of finance, especially where illegal sources (so-called loan sharks) were involved. Our best estimate is that the overall finance additionality for the sample would fall below 50 percent, compared to the 63 percent obtained in our analysis of bank finance alone.

The difficulty of establishing the level of additionality was confirmed when the topic was viewed from another perspective. The bankers were asked to state the principal reason why their customer was granted a CGC loan (see Table 5 overleaf). 
Table 5. Selection Criteria for CGC Loans

\begin{tabular}{lc}
\hline Criterion & No. of cases \\
\hline High risk & 2 \\
Insufficient security & 9 \\
Sound track record & 16 \\
Cheaper interest rate & 2 \\
To meet quota & 3 \\
Total & 32 \\
\hline
\end{tabular}

The findings of Table 5 have to be treated with a degree of scepticism, because borrowers may have been selected for CGC loans for a combination of reasons. The CGC loan probably yielded 100 percent finance additionality where the reasons are "high risk" or "insufficient security". The most common influence was a "sound track record", however, implying that the facility would probably have been granted unsecured, or that creditworthy customers are selected until the quota is achieved. The quota was cited as the dominant factor in three instances: the bankers strongly hinted that CGC loans were simply offered to pre-selected customers until the quota was exhausted.

The behaviour of the bankers is thus at odds with the objective of the PGS. However, a cautious attitude is understandable, as their promotion prospects of banking staff may be harmed by the incidence of bad debts. In the UK, as stated above, a high default rate was associated with cases of high finance additionality. If action is taken to reduce the level of default, it may have undesirable side effects. Neither the Loan Guarantee Scheme nor the PGS, for example, insist upon a specified level of personal commitment from the borrower; such a condition would reduce the incidence of default, but also tend to reduce finance additionality by denying finance to owners lacking resources. 


\section{Economic Additionality}

This concept has two broad elements: the direct benefit for the SMEs in terms of increased employment, profits or output; and the indirect impact on the wider economy. Economic additionality should strictly be calculated with reference to those firms which receive "additional" finance; but because of problems in establishing the level of finance additionality, this pre-condition has been ignored.

The direct benefit to the recipients will depend, to a large extent, on the way in which the funds are utilized. In 29 of the 32 firms, the borrowers claimed that the finance was used in accordance with the original application. (Two borrowers bought goods for their own use, while the other simply onlent the funds at a higher rate of interest.) In each of the 29 cases, the funds were used for working capital purposes hence it was difficult to establish a direct link between the CGC loan and the subsequent progress of the firm. Furthermore, the provision of funds for working capital is probably less likely to lead to sustainable rises in employment and output than expenditure on fixed assets.

Table 6. CGC loans: impact on employment

\begin{tabular}{lc}
\hline Employment & Number of firms \\
\hline Overall position & 21 \\
Increase & 1 \\
Decrease & $\frac{10}{32}$ \\
No change & \\
Total & 14 \\
Breakdown of 21 “increases" in employment & 5 \\
Increase of 2-4 & 2 \\
Increase of 5-10 & $\frac{21}{}$ \\
Increase of 11-15 & \\
Total &
\end{tabular}

The majority of firms had nevertheless increased employment since receiving the CGC loan; the 32 firms increased their workforce by 110 people (178 to 288 employees). However, significant increases in employment were confined to just two firms (Table 6). Even after the improvements shown in Table 6, there were fewer than five employees in 19 of the sample firms. This is significant because, for example, small provisions shops 
providing a living for the owner and his family are not likely to provide a major boost for employment in the economy.

With regard to profits and turnover, most firms (27 out of 32) reported enhanced performance, but they were unable to quantify the effect of the CGC loans. The Pieda study (1992, p.67) produced very similar results, stating that "almost all" of the firms which felt able to comment on this issue considered that output, employment and profit were higher than would have been the case without the Loan Guarantee Scheme loan.

The second element of economic additionality takes account of displacement effects, i.e., whether additional activity in the assisted firms translates into corresponding increases in the level of activity in the SME sector or the economy as a whole. In the Pieda study (1992, Chapter 8), economic additionality was found to be low where service sector firms, especially retailers, were involved. Manufacturing firms generally have a greater economic impact and create jobs. At the national level, it was rare for LGS-assisted firms to export their products or substitute for imports.

On this basis, indirect economic additionality in our sample (and the wider population of CGC-backed firms) would be expected to be low. While most firms had attracted new customers since receiving the CGC loan, these customers were usually (22 out of 32) from within a 50 mile radius of the firm's site and almost always (30 out of 32) located within the state. Only two firms had captured any export business. The implication is that CGC funding has largely displaced local activity.

Another strand of indirect economic additionality concerns the ability of small firms to create a more dynamic and innovative society. We judged that a minority of wellmanaged firms demonstrated a very positive attitude towards expansion. For example, one firm specializing in homeopathic medicines had increased its workforce significantly and begun to export to the Middle East and the former Soviet Union. By and large, however, the firms were content with modest progress, selling (or producing) fairly basic goods for a parochial market. Apart from the computer-related firms, the use of new technology was very modest. 


\section{The New PGS}

It is acknowledged that any conclusions drawn solely from our pilot study have to be tentative, in view of the sample size. However, secondary data produced by the CGC and Bank Negara have tended to confirm the survey findings. Overall, the CGC's effectiveness in meeting the needs of SMEs, banks and the wider economy appears to have been somewhat limited. Nevertheless, the CGC has been given a high profile without official efforts to encourage the growth of SMEs. In these circumstances, the successful implementation of the New Principal Guarantee Scheme is critical.

The New PGS is designed to cater for the needs of larger companies, especially those operating in priority sectors specified by the government, notably the manufacture of high technology and resource-based products. The value of credit facilities eligible for guarantee and the level of guarantee coverage were increased. The interest margin was raised to 2.0 percent over the base lending rate, while the guarantee premium was left unchanged. As a result, the total cost for borrowers is now comparable with other guarantee schemes across the world. Decisions on utilization, by borrowers and lenders alike, should thus increasingly be taken on the basis of rational economic and risk factors (Kanbur, Boocock and Hwa, forthcoming).

The guarantee under the New PGS, covering 70-90 percent of the borrowing, can be used in two ways. It can either cover all facilities made available at the time of approval, or the lender can take the secured part of the lending package outside the arrangements with the CGC (as with the "old" PGS). In the case of a firm wishing to borrow RM200,000, with collateral valued at RM100,000, the lender could choose to have all the borrowing guaranteed by the CGC or simply the excess over the security. The inclusion of loans backed by collateral should mean that the CGC's overall portfolio of loans is less risky.

The initial take-up of the New PGS has been extremely impressive (see Table 1). In the period March-December 1994, 3146 loans were granted, with a total value of RM530.1m. A detailed breakdown of these figures is not available, but the increase in 
uptake has probably stemmed from a combination of factors: the use of the guarantee to cover all borrowing, rather than the excess over the value of collateral which has meant that the average value of each loan has risen sharply; the opportunity for finance companies, as well as banks to provide CGC loans for the first time; and the conversion of conventional bank or "old" PGS loans to the new Scheme.

\section{The New PGS: an improved loan scheme?}

The stated objective of the New PGS is to achieve high levels of uptake and economic additionality, but thorny issues of finance additionality and the default rate have not been addressed.

The relationship between lenders and the CGC does appear to be improving, and the CGC is determined that this trend should continue. The terms and conditions of the New PGS were announced only after extensive consultation with the financial community. Furthermore, changes introduced recently, removing the CGC's ex-post evaluation of the banks' appraisal, should help to facilitate the payment of claims. If the initial uptake of the Scheme is to be sustained, financiers must be convinced that guarantees will be honoured.

The quotas for CGC loans have been retained, despite their potentially harmful effect on the relationship between the CGC and the lenders, and their debatable impact on finance and economic additionality. The imposition of official guidelines may have been required to give impetus to the CGC's operations in its early years, but they may perhaps have served their purpose. If the New PGS were attractive to borrowers and lenders alike, its usage could be left to market forces.

The degree of finance additionality found in the pilot study was questionable, mainly because it proved difficult to isolate the influence of quotas. With the retention of the quota system, it is hard to judge whether additionality will improve or decline for the New PGS. The higher level of guarantee cover and improved interest margin should encourage banks and finance companies to direct high risk SMEs to the scheme 
voluntarily. Nevertheless, it is not easy to explain the surge in borrowers from an SME sector which remains fragmented and traditional in outlook, especially as the responsibility for selecting firms remains with the lenders, and the temptation to use New PGS loans as replacement finance is still present.

Turning to economic additionality, the pilot study suggested that local displacement effects were high, export activity or import substitution was low and innovation was infrequent. For the New PGS to achieve a higher degree of economic impact, the CGC's portfolio of companies will have to be radically altered. Unfortunately, detailed information on New PGS- backed companies is not yet available. The critical problem is how to reconcile the differing objectives of the various parties: the CGC, banks, SMEs and the authorities. For example, the exclusion of certain types of propositions (particularly retailers) would offer higher economic additionality, but a preponderance of high risk innovative companies would tend to result in increased bad debts.

\section{The Implications for other Guarantee Schemes}

The balance between helping high risk enterprises, which cannot obtain conventional bank funding, and loan losses will always be a delicate one. The successful operation of any loan scheme therefore has to be based upon mutual co-operation between the guarantee provider, financial institutions, the authorities and SMEs. All parties have to recognise their rights and responsibilities.

A key element of "good practice" in operating a loan scheme is that lenders should approve loans "only when they are convinced that the project is viable ... and they (the lenders) will make all possible efforts to collect loan repayments" (Levitsky, 1993). In addition, successful loan schemes do not rely entirely on the lenders to appraise and monitor the borrowing. The experience of the CGC reinforces the value of Levitsky's comments. Banks in Malaysia have committed funds to projects which have resulted in a high level of non-performing loans. The CGC has been powerless to assist the banks in gaining repayment of the loans, operating from a single office and having no contact with the SMEs. 
More generally, the activities of the CGC illustrate the problems of trying to tackle an ambitious agenda without the required level of support services. (This situation may change, as the CGC has announced its intention to establish a unit to offer training, advisory and consultancy services for SMEs.) The CGC currently has obligations to firms ranging in size from "hawkers and traders" to larger firms operating in the government's priority sectors, as well as a continuing obligation to assist Bumiputera borrowers. A rationalisation of schemes might result in a more focused and credible approach.

The experience in Malaysia also suggests that attempts to distort market forces, by imposing quotas, have not resulted in high levels of finance and economic additionality.

Finally, the case for any government-backed loan scheme rests upon the conclusion that, without such schemes, private sector financial institutions would deny finance to viable firms which lack security. Given the rate of default associated with SMEs, such a scheme will almost certainly contain an element of subsidy. In the United Kingdom, for example, the net cost of operating the Loan Guarantee Scheme (guarantee payments less premium income and security realisations) has been estimated with some degree of certainty (NERA, 1990, p.41; Pieda, 1992, p.4). The scheme's lending was found to be marginally unprofitable for the banks, and the direct cost to the public purse was substantial. However, when the positive impact arising from additional economic activity was taken into account, the scheme produced a surplus for the UK Treasury. In these circumstances, the UK banks were (and are) prepared to participate in the scheme. By contrast, as stated above, information on the costs of operation for the CGC are not made available. A more open approach to disclosure, with a breakdown of the costs for individual schemes, might encourage sustained usage of the New PGS. The lesson for other schemes is that the operating costs have to be (and be perceived to be) shared equitably. 


\section{REFERENCES}

Bank Negara, (1992 and 1993), Annual Reports, Bank Negara, Kuala Lumpur.

Chee Peng Lim, (1986b), Small Industry in Malaysia, Berita Publishing Sdn Bhd, Kuala Lumpur.

Fong Chan Onn, (1990), 'Small and medium industries in Malaysia: economic efficiency and entrepreneurship', Developing Economies, XXVIII, June 1990, pp.152-79.

Greenwald, B., A. Weiss, and J.E. Stiglitz, (1984), 'Informational imperfections in capital markets and macro-economic fluctuations', American Economic Review, Vol. 74, pp.174-200.

Kanbur, M G., J.G. Boocock, and Yen Siew Hwa (forthcoming) 'The determinants of the utilisation of government-backed loan schemes for SMEs: a case study of Malaysia', Singapore Economic Review.

Levitsky, J. and R.N. Prasad, (1987), 'Credit guarantee schemes for small and mediumsized enterprises', World Bank Technical Paper No 38, Industry and Finance Series, Washington D.C., World Bank.

Levitsky J., (1993), 'Credit guarantee funds and mutual guarantee systems', Small Enterprise Development, Vol. 4, No. 2, pp.4-15.

Lin See-Yan, (1994), 'The financing of small-scale enterprises in Malaysia', MCA Conference Proceedings, Kuala Lumpur, 10 April, unpublished.

NERA (National Economic Research Associates), (1990), 'An evaluation of the loan guarantee scheme', Research Paper No. 74, London, Dept. of Employment. 
Phang Hooi Eng, (1992), 'Proposals for co-operation in finance', in Kim Seung Jin and Suh Jang-Won (ed.) Co-operation in small and medium-scale industries in ASEAN, Asian and Pacific Development Centre, Kuala Lumpur, pp. 117-45.

Pieda plc, (1992), Evaluation of the Loan Guarantee Scheme, London, Department of Employment.

Pletcher, D.D. and D.H. Tootelion, (1989), 'SBA loan recipients - an expanded study of borrowers', California State University: Sacramento.

Rhyne, E.H., (1988), Small businesses and SBA loan guarantees - subsidising the weak or bridging a credit gap? Quorum Books, New York.

Robson Rhodes, (1984), 'A study of businesses financed under the Small Business Loan Guarantee Scheme', London, Department of Trade and Industry. 